\title{
原著＼cjkstart振動工具使用者の末梢循環機能の推移
}

\author{
二 塚 信*
}

\section{THE CHANGE OF PERIPHERAL CIRCULATORY FUNCTION OF THE VIBRATING TOOL USERS}

\author{
Makoto FUTATSUKA $\dagger$
}

Six workers who had used chain-saws for about 5 to 6 years and suffered from repeated attacks of Raynaud's phenomenon were chosen and the changes of their peripheral circulatory functions, peripheral nerve functions and subjective symptoms were investigated before and after the introduction of bus survice for their daily transport.

The results revealed that, though the Raynaud's phenomenon per se subsided remarkably after stopping riding bicycles to the working spot, possibly by reducing the chance of inducing the phenomenon, the peripheral circulatory and nerve functions as well as other local and general symptoms still showed a tendency to get worse.

From the data, it is suggested that the occurrence of Raynaud's phenomenon may be attributed not only to the quantity but also to the quality of the induction risk. So we should pay attention to the persistent peripheral circulatory functions, considering it as one of the important diagnostic criteria for the diagnosis of vibration hazards irrespective of the existence or absence of the Raynoud's phenomenon.

\section{I. は じめに}

振動障害は広く白ろら病と呼びならわされているよう 飞, 手指にみられるレイノ一現象の特異性のゆえに世間 の耳目を集めた一面があった1)、しかしながら，その後 の研究の進展にともなって, レイノ一現象の発症の有無 にかかわりなく，チェーン・ソーなど振動工具使用者に は，末梢循環領域のみならず，かなり中枢側にまで，機 能的にも器質的にも循環障害が常在化していることが明 らかにされつつある2,3).

また，他面，林業労働でのチェーン・ソー作業の場 合，造船所や鉄鋼工場の場合と違って，自宅から山間辺 地の作業現場まで，長距離のしかも不便な通勤が拘束さ れ，ほかに適当な交通手段を持ちえない林業労働者は， 単車による通勤を余儀なくされた．寒冷期の山間林道で の単車通勤は, 全身寒冷暴露と手指の円滑な血流を阻害

* 熊本大学医学部公衆衛生学教室（主任：野村 茂教授) 昭和 48 年 3 月 7 日受付

$\uparrow$ Department of Public Health, Kumamoto University Medical School (Director: Prof. S. Nomura) Received for publication, March 7, 1973.
せしめる姿勢とによって，チェーン・ソ一使用者の常在 性の循環障害を背景としたレイノ一現象を誘発させる恰 好の機会となったことも事実である4).

近年, 振動障害に対する健康管理対策の一環といら意 味もあって, 人員輸送車（マイクロバス）による集団通 勤が広く普及しつつある.また，個人通勤の場合も，モ 一タリゼーションの風潮のなかで, 従来の単車に代わっ て軽四輪あるいは普通乗用車によるるのが一般化しつつ ある。

これは, 現地疫学的に, レイノー現象の全体的な検討 を行なららえでまたとない機会である.すなわち，この ような, 直接振動工具の使用条件そのものの変更を伴わ ない, いわば副次的な労働条件の变貌が進行していくな かで, 振動工具使用者のレイノ一現象発症の様態に変化 がみられるか, 末梢循環機能に変化がみられるかどらか を観察し, ひいては, 振動障害の病態のなかで, 末梢循 環機能抢よびレイノ一現象のもつ意味と, その位置づけ を検討し，若干の知見を得たので，その成績を報告す $る^{5)}$. 


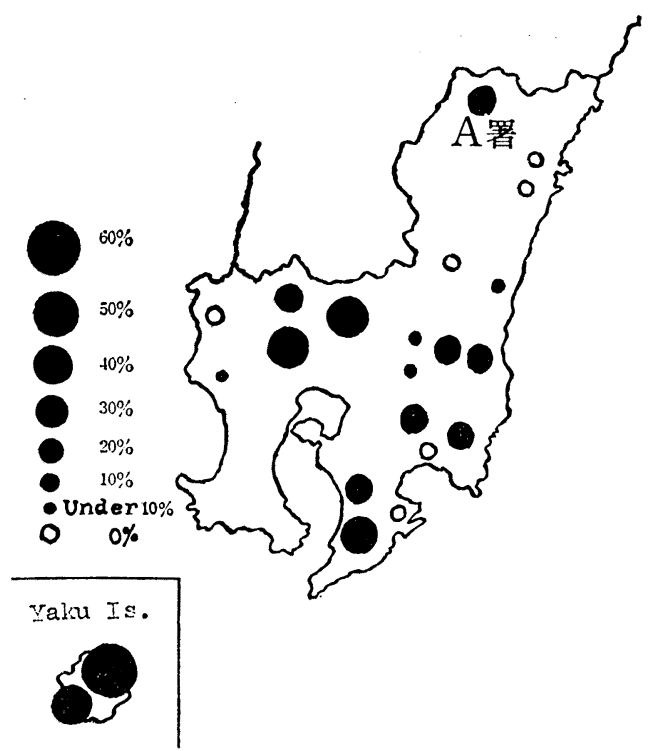

Fig. 1. Regional distribution of the incidence rate of Raynoud's phenomenon among chainsaw workers in southern Kyushu district.

\section{II. 研 究 方 法}

宮崎県 $\mathrm{A}$ 営林署管内のチェーン・ソー作業従事者のう ち, 昭和 41 年 1 月の時点で, 手指のレイノ一現象, しび れ感，知覚鈍麻などを認めた 6 名と何ら所見のない 2 名 を対象に, 単車に代わる人員輸送車導入前後の自覚症状 ならびに末梢循環機能, 末梢神経機能の変動を観察し た. 人員輸送車導入前については昭和 41 年 1 月に行な い, 同42年12月の輸送車導入をはさんで，導入後につい ては同43年 4 月，まったく同様の方法で再度調查を行な った.

なお，A営林署管内のレイノ一現象発症率は Fig. 1 のごとくで, 南九州のなかでも比較的高率の発症をみて (る ${ }^{6)}$.

調査対象の職業歴はTable 1 のごとくで, 著者の 2 回 の調査の間には特記すべき作業条件の変更は認められな かった.

調査内容は，末梢循環機能を検討するために，反応性 充血現象の検討7) および手指冷却に伴う皮膚温の変動を 検討した ${ }^{8)}$. また，末梢神経機能については，一般胸腹 部の診察, 神経学的臨床検查ならびに四肢末梢の痛覚・ 振動覚閾値を検討した ${ }^{6)}$.

\section{III. 研 究 成 績}

人員輸送車の導入前後の自覚症状の変化は Table 2 の
Table 1. Occupational history of the male chain-saw cutters investigated.

\begin{tabular}{c|ccc}
\hline Subject & Age & $\begin{array}{c}\text { Begin of } \\
\text { chain-saw } \\
\text { operation }\end{array}$ & $\begin{array}{c}\text { Experience of } \\
\text { chain-saw } \\
\text { operation }\end{array}$ \\
\hline A & 51 & 1961.5 & 5 years \\
B & 48 & 1960.5 & 6 \\
C & 40 & 1960.5 & 6 \\
D & 53 & 1961.5 & 5 \\
E & 54 & 1960.5 & 6 \\
F & 41 & 1960.5 & 6 \\
\hline G & 35 & 1961.5 & 5 \\
H & 33 & 1960.5 & 6 \\
\hline
\end{tabular}

ごとくである.すなわち, 導入後においては,レイノ一現 象有症者 6 名のうち, レイノー現象の消失をみたもの 3 名, その発症様態が軽快（範囲の狭小化と頻度の低下） に傾いたもの 2 名と, レイノ一現象そのものの消螁化の 傾向は顕著なものがある．他方，手指のしびれ感などの 知覚異常は, 消失したもの 1 名, 軽快したもの 2 名であ るのに対して, 増悪したもの 3 名, さらに比較対照者に も 1 名発症をみている. また, 手指や上肢の疼痛は, 消 失したもの 1 名, 軽快したもの 1 名, 変わらないもの 3 名, 増悪したもの 1 名と, 神経・筋症状は必ずしも軽快 していない.

次に, 手指冷却に伴う皮膚温の変動は Table 3 のごと くで, 手指冷却時の寒冷血管抎張反応 (cold dilatation), 冷却時後半 5 分間の平均皮膚温, 冷却直後の皮膚温の上 昇傾向（皮膚温回復能）のいずれの指標も全体としては すべて増悪の傾向を示している.

昭和41年 1 月の時点では，自覚的にはレイノ一現象が 頻発するにもかかわらず，他覚的には，寒冷血管払張反 応が不明瞭ながら一応は認められるものや，平均皮膚温 が $9 \sim 10^{\circ} \mathrm{C}$ と末梢循環障害の程度は軽いとみなされるす のも若干認められた. しかし，43年 4 月では, 逆に, レ イノ一現象そのものは消失ないし軽快しているにもかか わらず，他覚的には，とくに Magos らが職業性レイノ 一症候群解明の糸口にもなりらるのではないかと注目し ている ${ }^{9)}$ 寒冷血管拡張反応が対象全員に消失し, 平均皮 虐温も一例を除いては $2 \sim 3^{\circ} \mathrm{C}$ の明瞭な低下を示した. 以上の成績は, いずれも, 末梢循環障害の程度が, むし ろ中等度ないし高度に進行していることを示唆してい る.もっとも, 皮膚温回復能のみは, レイノ一現象の消 失をみた 3 例のうち 2 例に上昇を認めた。 この 2 例は, 昭和 41 年 1 月には，レイノ一現象が頻発するにもかかわ 
Table 2. Changes of subjective symptoms before and after the introduction of bus transport.

\begin{tabular}{|c|c|c|c|c|c|c|c|c|}
\hline & A & B & $\mathrm{C}$ & $\mathrm{D}$ & $\mathrm{E}$ & F & G & $\mathrm{H}$ \\
\hline First appearance of Raynaud's $P$. & 1963.10 & 1962.12 & 1963.10 & 1963.11 & 1962.11 & 1963.10 & - & - \\
\hline $\begin{array}{l}\text { Years of experience before the } \\
\text { first appearance of Raynaud's P. }\end{array}$ & $2 \mathrm{y} .5 \mathrm{~m}$. & 2.7 & 3.5 & 2.6 & 2.6 & 3.5 & - & - \\
\hline $\begin{array}{l}\text { Duration from the first appeara- } \\
\text { nce of Raynaud's P. to the pre- } \\
\text { sent. }\end{array}$ & $2 \mathrm{y} .3 \mathrm{~m}$. & 3.1 & 2.3 & 2.2 & 3.2 & 2.3 & - & - \\
\hline Raynaud's Phenomenon & (0) (0) & (2) 0 & (2) 0 & (2) $\times$ & (0) $\times$ & (a) $\times$ & $\times \times$ & $\times \times$ \\
\hline Sensory disturbances & 00 & $\circ$ (?) & (a) 0 & $0 \times$ & (a) 0 & 00 & $\times 0$ & $\times \times$ \\
\hline Pain (finger, hand) & (-) () & $\circ 0$ & (2) 0 & $0 \times$ & () & (2) () & $\times \times$ & $\times \times$ \\
\hline Other findings & 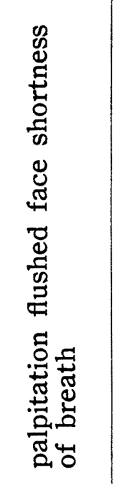 & 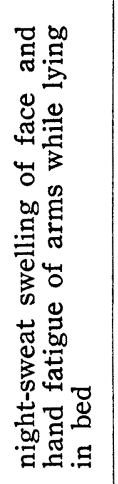 & 1 & 1 & 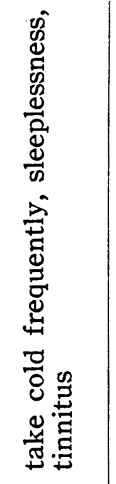 & 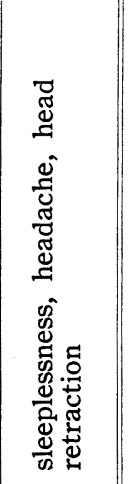 & 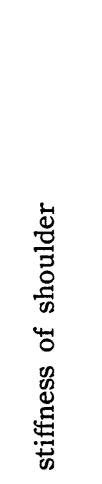 & 1 \\
\hline
\end{tabular}

severe $($ ), moderate $\bigcirc$, normal $\times$ (left columns: Jan., 1966, right: Apr., 1968)

Table 3. Changes of physiological findings before and after the introduction of bus transport.

\begin{tabular}{|c|c|c|c|c|c|c|c|c|c|}
\hline & A & B & $\mathrm{C}$ & $\mathrm{D}$ & $\mathrm{E}$ & $\mathrm{F}$ & G & $\mathrm{H}$ \\
\hline \multirow{4}{*}{ 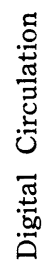 } & reactive hypermia & $-\quad-$ & \pm \pm & $-\quad-$ & \pm \pm & \pm \pm & \pm- & + \pm & ++ \\
\hline & CIVD & $-\quad-$ & \pm- & \pm- & +- & \pm- & +- & $H-$ & ++ \\
\hline & $\begin{array}{l}\text { average skin temperature } \\
\left(6^{\prime}-10^{\prime}\right)\end{array}$ & 9.27 .0 & 7.59 .1 & 8.86 .7 & 9.97 .3 & $10.3 \quad 10.0$ & 10.07 .7 & 13.39 .4 & 11.511 .3 \\
\hline & $\begin{array}{l}\text { recovery activity of skin } \\
\text { temperature }\end{array}$ & 2.82 .2 & 4.13 .5 & 2.62 .6 & 2.02 .9 & 1.73 .0 & 4.42 .8 & 3.92 .8 & 3.53 .6 \\
\hline \multicolumn{2}{|c|}{ Threshold of pain sensation } & 010.0 & $4.0 \quad 10.0$ & $0 \quad 10.0$ & 02.0 & 02.0 & 02.0 & 0.51 .0 & 01.0 \\
\hline
\end{tabular}

left columns : Jan., 1966, right: Apr., 1968.

らず, 皮膚温回復能の顕著な低下を除いては, 他の指標 はいずれる他に比し軽症の例である. かかる意味に执い $\tau$, 皮膚温回復能の生理的意義は, レイノ一現象の発現 機序を支配する生理的要因と直接関連があり, 他の末梢 循環指標とはやや異なる意味を持つことが考えられる. ちなみに, レイノ一現象が消失したものと比較対照者の
導入後に扣ける手指冷却に伴う皮膚温の変動はFig. 2 の ごとくである.この 2 例は，いずれむ，自覚的にはレイノ 一現象の発症をみないるのであるが, 冷却中および冷却 後の皮膚温のレベルが明らかに異なっていることを示し ている. 調查対象の人員輸送車導入前後の平均皮虙温の 変動はFig. 3 のごとくで, 程度の差はあれ, 対照も含め 


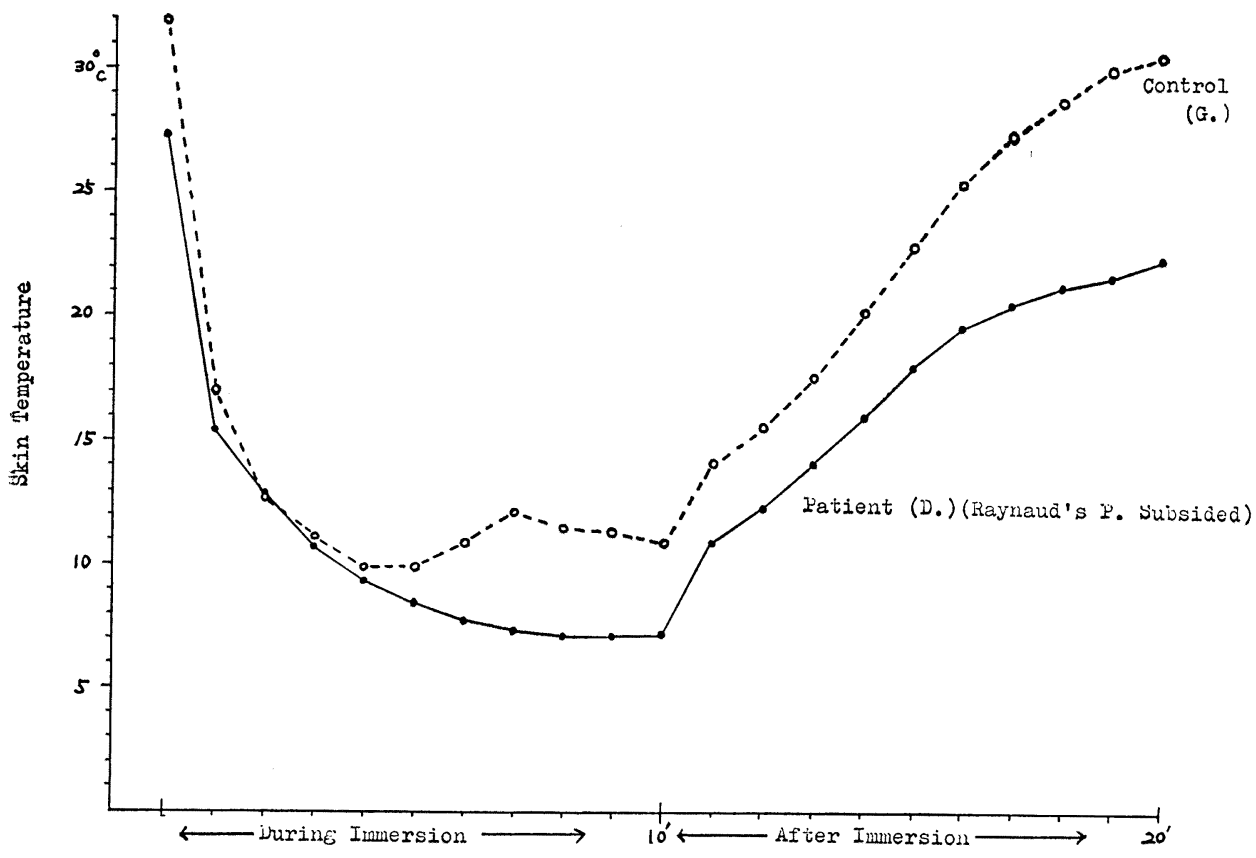

Fig. 2. Changes of skin temperature during immersion of the hand in the cold water. (Apr., 1968)

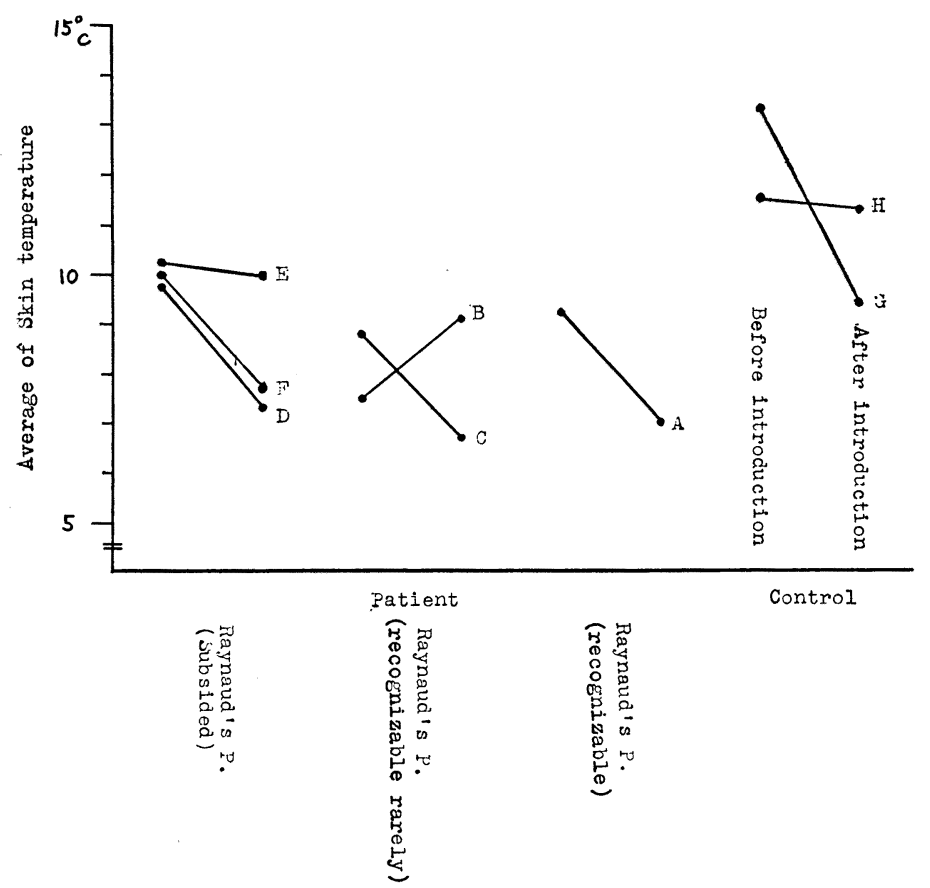

Fig. 3. Changes of skin temperature and the introduction of a transport bus. 

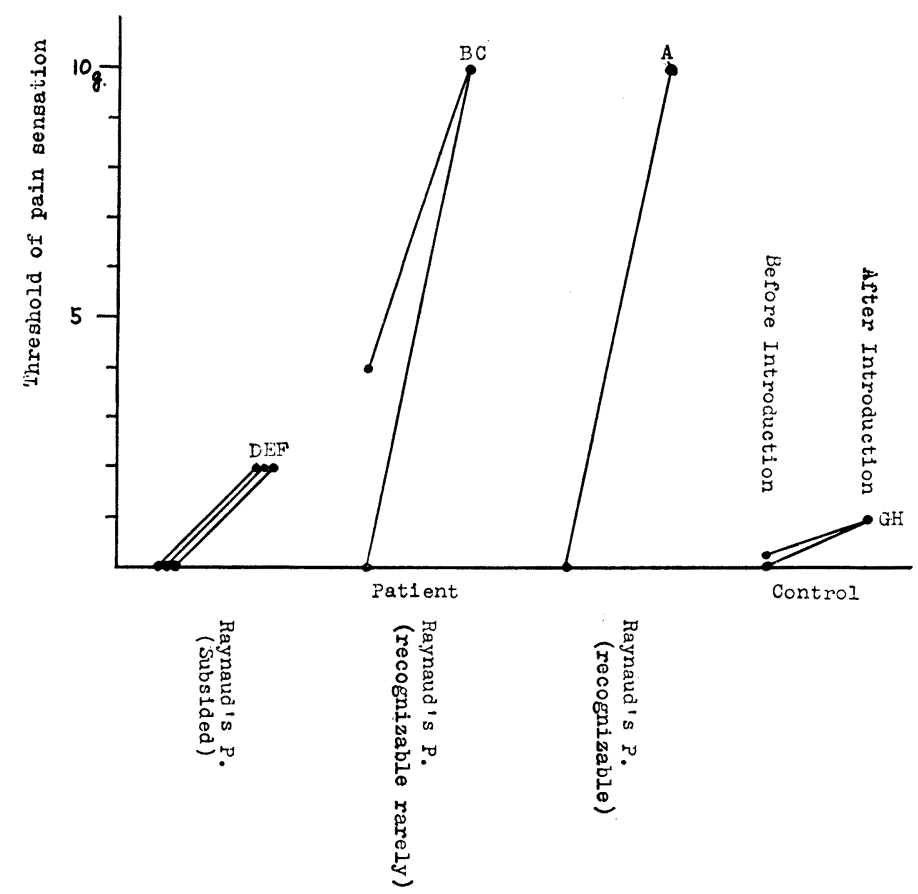

Fig. 4. Change of sensory threshold of pain by the introduction of a transport bus.

て，自覚症状の有無にかかわらず，いずれも低下の傾向 を明瞭に示している.

また，手指末梢における痛覚閾値の変動はFig 4.のご とくで,昭和 43 年 4 月には, 対照も含めて全員に間値の上 昇がみられる，閾值上昇の程度は，レイノ一現象が消失 したものと比較対照者はほぼ同程度で，いずれも比較的 小さい。これに対して，レイノ一現象発症が軽快したも の, 変わらないものはいずれも顕著な鈍麻の傾向を示し た.

このよらな末梢知覚障害の経過は, レイノ一現象発症 の推移とは直接関連なく進展しつつあり, その程度はむ しろ末梢循環障害のそれよりも大きなものがある．これ らの成績は著者らがすでに報告したごとく ${ }^{10,11)}$ ，一般的 に両者は相並行しながら進展しつつ, 末梢循環障害の進 行が先行し, 回復過程においても, 末梢神経障害の軽快 が遅延するという傾向を prospective に示唆したものと して興味深い.

いずれにしても，程度の差はあれ，自覚的なレイノー 現象発症の有無にかかわりなく，2 年余のチェーン・ソ 一使用の蓄積のなかで, 末梢神経障害と末梢循環障害と は相並行して進行しつつあることを示している.

さらに, Table 2, 3 のごとく, レイノ一現象の消煺に
伴って, 自覚的には神経・筋症状が軽快した若干のもの にも，むしろ，他覚的には末梢知覚閾値が上昇している ことは注目すべき所見である.

\section{IV. 考察}

Loriga の報告 ${ }^{12)}$ 以来, 振動工具の使用に基因する振 動障害の診断は, レイノ一現象の発症を最終的なよりど ころにしてきた. それは，レイノ一現象というきわめて 特異的な現象をごく容易に客観的に確認できるために， 振動障害患者を早期に発見して健康管理の対象とするた めにも, 振動障害の研究を推進するうえでの対象選定の 振標としても，それなりの意義はもっていたといわなけ ればならない, しかしながら, 他面, 職業性レイノ一症 候群をレイノ一病とは区別して, 二次性の疾患の範疇に 位置づけられているごとく13)，レイノ一現象のほかに局 所振動の影響が当然のことながら考慮されなければなら ない" ${ }^{14)}$. しかしながら, 産業医学の実践の場で, レイノ 一現象と振動障害としての末梢循環障害の関係が必ずし. も明確にされているとはいいがたい.

著者は, 振動工具自体の使用条件はほとんど変更され ることなく, 振動工具使用者の通勤形態が単車から人員 輸送車によるものにきりかえられた機会をとらえて，レ 
イノ一現象発症の消長と末梢循環機能, 末梢神経機能の 消長とを疫学的に把握し, 両者の関連性を検討すべく本 調査を企画した.

ここで問題にしたのは, 第一に振動工具による末梢循 環障害のすべての側面が現象的にもレイノー現象として 集約しえるかといらことであり, 第二に診断学的にみた 場合のレイノ一現象の意義と限界とを明らかにすること であった.

振動工具使用者で, レイノ一現象を有するるのには,す でに Junghaus や Mills のごとく, Biopsy の所見から 器質的な障害を認めた報告 ${ }^{15)}$, Ashe のごとく血管造影

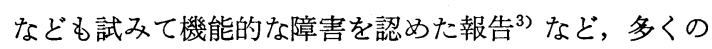
業績が積まれている ${ }^{16)}$. しかしながら, 病像を検討するに 当たって, 他の職業のものと林業労働者の差異, 林業労 働者のらち振動工具使用者と非使用者の差異, 振動工具 使用者のらちレイノ一現象有症者と無症者の差異を検討 するといった系統的な詰めができていないために，振動 工具による末梢循環障害のすべての側面をレイノー現象 として集約することは当を得ないという基本的了解には 立っているようにみえるが，レイノ一現象とこれら病態 との直接的な関連について触れることは比較的少なかっ たように思われる.

すでに触れたごとく，振動工具を使用しているかぎ り, 単車走行という恰好の誘発機会を失ったことによっ てみられたレイノ一現象の消褪化とはまったく無関係 飞, 末梢循環障害, さらには末梢神経障害ともに一定の 進行がみられた．ここに，レイノー現象の消長と末梢循 環障害の消長とがまったく相反することもありらること が現地疫学的に確認された。

これらの成續は, レイノー現象が現象論的には振動障 害の一面を的確に表現してはいるものの, 振動工具の使 用による末梢循環障害の病態そのものとは一義的には結 びつかないこと, 少なくともレイノー現象は総体として の末梢循環障害の部分的な側面ではないかと考えられ る. 振動障害患者にみられるレイノ一現象は, 常在性の 末梢循環障害を基礎に, ある種の誘発機会をひきがねと して，かなり偶発的に発生する現象とみなされる ${ }^{17)}$ 、レ イノ一現象発症の様態は, Table 2 のごとく, 末梢循環 の程度が少なくともある一定のレベルにとどまっている 場合には，もっぱら，ひきがねとしての誘発機会に遭遇 するレベルに規定されているということができる. 本研 究においても，B例やC 例は，いずれも末梢循環機能は 増悪の傾向を示した例であるが，単車に乗らなくなって レイノ一現象発症の頻度は著しく減じたが，冬季，みぞ
れの中での作業あいまの休敗時などにはレイノ一現象の 発現をみると述べている.

かかる意味において，レイノ一現象の持つ診断学的な 意味はおのずから明らかである.すでに報告されたごと く, レイノー現象を認めるものは少なくとも振動障害患 者とみなすことができるが，逆に，レイノ一現象を認め ないもののなかにも, 振動工具の使用によって末梢循環 障害をきたしたものが少なからず存在することを示唆し

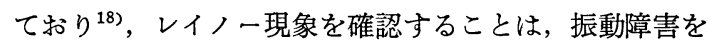
診断するに当たって, 十分条件ではあっても, 必要条件 ではありえないと考えられる ${ }^{19)}$.

ことに近年, 単車にかわって, マイクロバスあるいは 乗用車による通勤が一般化しつつあり, チェーン・ソー 使用条件の変化ともあいまって, 表面的にはレイノ一現 象を訴えるものの数は減少しつつあるかのごとくであ る.レイノー現象の確認による患者の診断では，その限 界があることはすでにくり返し述べたが，レイノ一現象 以外の訴えの増加ともあいまって, 現実の振動障害の実 態との間のギャップはむしろ大きくなりつつあるとも思 われる. したがって, 振動障害患者としての健康管理を 受けるべくして受けえない作業者の層が大きくなる可能 性のあることを指摘したい.すずに，著者らは，昭和 46 年から47年にかけての南九州に拈ける調査のなかで, か かる事実が広く存在することを痛感した ${ }^{20)}$.

かかる意味に沶いて, 一応, レイノ一現象発症の有無 とは無関係に, 振動工具使用者の末梢循環機能の特性を 再検討し, レイノ一現象との関連, その他の機能との関 連を吟味する必要があると考える。

\section{V. 結 語}

振動工具（チェーン・ソー）を 5 〜 年にわたって使 用し, レイノ一現象の頻発をみていた 6 名の作業者につ いて, 人員輸送車導入前後のレイノ一現象その他の自覚 症状および末梢循環機能, 末梢神経機能の推移を検討し た. その結果, 単車による通勤を中止したことによっ て，レイノ一現象の発症そのものは著しい消褪をみたに もかかわらず, その他の局所的, 全身的症状や末梢循環 機能，末梢神経機能はいずれも増悪の傾向を示した。以 上の成績から，レイノ一現象発症の程度は, ある一定の 生体レベルに拈いては, 発症誘発の機会への暴露の程度 に規定されること，したがって，振動障害の診断に当た っては, レイノー現象発症の確認を必要条件とすること は著しく疑問であることが指摘できる.すなわち、レイ ノ一現象の有無によって振動障害患者をスクリーニング 
することは危険であるといわなければならない。

かかる意味において, 広く, 振動工具使用者の末梢循 環機能の特性を把握し, レイノ一現象との関連, その他 の機能との関連を再検討する必要がある.

最後に，このような成績が，林業労働者の単車通勤か ら人員輸送車通勤へのきりかえの積極的意義をとこなら ものではないことを強調したい.すでに述べたごとく， 単車通勤によって薏起される多くの悪条件を断つことは 振動障害発生予防にとっても重要な意味があり,すでに 外国でも，わが国の国有林でも振動障害に対する健康管 理対策の一環として，人員輸送車による通勤が普及しつ つある ${ }^{21)}$.ただし，そのことによって，すでに詳述した ごとく，レイノ一現象の誘発が減じたことをもって，振 動障害自体が軽快したとみるのは䛊りで, むしろ, 常在 性の諸々の障害を系統的・持続的な健康診断で早期に発 見し，早期に健康管理をすることの重要性がますます増 大したとみるべきである.なぜならば，このような対策 が講じられないかぎり,むしろ, 著者の経験した症例の ごとく，レイノ一現象を発症しないがゆえの潜在化の傾 向がより大きくなる可能性が強いことを強調したい。

稿を終えるに当たり，ご指導をいただいた野村 茂教授，高 松 誠教授に感謝の意を表します，また，本研究に際して，共 同して調査に当たっていただいた前田 寛先生，上田忠子先生 に拈礼申し上げます，さらに，本研究に多大のご協力をいただ いた能本営林局の関係各位に厚くお礼申し上げます。

本論文の要旨は, 昭和 45 年 4 月, 徳島市における第 43 回日本 .産業医学会総会にて発表した.

\section{文献}

1）山田信也：山林労働と白ろう病, 社会医学双書 I, 161 205, 光生館, 1967.
2）渡部真也：振動工具使用者の手の血管の反応性, 産業医 学, 10(4): 98, 1968.

3) Ashe, W. F. et al.: Raynaud's phenomenon of occupational origin, Arch. Environmental Health, 9: 425 433, 1964.

4）山田信也：白ろう病撲隇のたたかいにとりくんで, 医学 評論, 30: 1 19, 1966.

5）二埭 信, 他：振動障害患者の末梢循環機能について, 第43回日本産業医学会総会講演集，441，1970.

6) 二塚 信: Chain Saw による振動障害に関する研究, 熊本医学会誌, 43(6)：467 524, 1969.

7）志場正光: 末梢循環障害の診断, 最新医学, 181: 1374 1385, 1961.

8）本田西男：皮膚血流の指標としての意義, 呼吸と循環, $12(2)$ : 897 904, 1964.

9) Magos, L. et al.: Cold dilatation and Raynaud's phenomenon, Arch. Environment. Health, 7(4): 402, 1963.

10）二塚 信，他：局所振動の生体作用について，第44回日 本産業医学会総会講演集, 116, 1971.

11）高松 誠, 二塚 信：全身性疾患としての白ろう病, 労 働の科学, $24(8)$ : 10 16, 1969.

12) Loriga, G.: Il lavoro coi martelli pneumatici, Boll. Ispett. Lavoro, 2: 35, 1911; 6: 524, 1913.

13）砂田輝武：レイノ一症候群, 最新医学, 181：1450 1456, 1961.

14）三浦豊彦, 他：局所振動障害としての職業レイノ一症候 群, 労働科学, 42(11): 725 747, 1966.

15) Gurdijian, E. S. et al.: Traumatic vasospastic disease of the hand (white fingers)., J. A. M. A., $129(10): 668 \sim 672,1945$.

16）高松 誠, 渡部真也: 振動障害, 職業病とその 対 策, 511 560, 興生社, 1969 .

17）鈴木継美：気温と白指発作との関係，産業医学，12(5)： $3 \sim 5,1970$.

18）山田信也：振動障害の経過, 労働の科学, $24(8) ： 17$ 26,1969 .

19）三浦豊彦，二塚 信，他：振動工具による振動障害の診 断について, 労働科学, $46(7): 399 \sim 421,1970$.

20）二侬 信, 後藤玩也, 他：振動工具使用者の末梢循環機 能について, (未発表資料)，1972.

21）渡部真也, 山田信也：ソ連林業に括ける振動病の対策と 研究, 三孔社, 東京, 1972 . 